\title{
Aplikasi Pemesanan Online Melalui Website Berbasis SMS Gateway Pada Multicom
}

\author{
Asep Hardiyanto Nugroho \\ Universistas Islam Syekh Yusuf Tangerang \\ J1. Maulana Yusuf No. 10, Babakan, Tangerang, Banten, 15118 \\ Hardiyanto.nugroho@gmail.com
}

\begin{abstract}
Abstrak - Multicom Koba merupakan perusahaan yang bergerak dibidang penjualan kemputer dan asesorisnya, yang mana perusahaan ini memiliki berbagai masalah, salah satunya adalah dalam hal pemasaran dan pelayanan terhadap pelanggan, hal tersebut dikarenakan selama ini dalam pemesanan barang hanya melalui handphone saja, sehingga dengan banyaknya pelanggan dan keterbatasan pegawai membuat Multicom Koba kewalahan dalam hal pelayananan terhadap pelanggan. Aplikasi pemesanan online melalui website berbasis SMS Gateway adalah suatu aplikasi yang dibuat dengan menggunakan bahasa pemrograman java dan database MySQL-front. Tujuan dari pembuatan aplikasi ini adalah untuk membantu pelanggan dalam mendapatkan informasi mengenai stok barang serta harga barang, sehingga pelanggan tidak perlu lagi datang ketempat, cukup dengan cara mengirimkan SMS ke aplikasi ini dengan format yang telah ditentukan, sehingga secara otomatis akan direspon oleh aplikasi ini. Cara mengirimkan SMS sama seperti kita biasanya, hanya format yang dipakai berbeda karena telah ditentukan oleh aplikasi ini. Selain cepat mendapatkan informasi, pelanggan juga dapat melakukan pemesanan dimanapun dan kapanpun.
\end{abstract}

Kata Kunci-- Aplikasi Pemesanan Online Melalui Website Berbasis SMS Gateway, MySQL, Java, SMS Gateway

\section{PENDAHULUAN}

Perkembangan ilmu pengetahuan dan teknologi yang semakin pesat, khususnya tekhnologi informasi dapat memberikan kemudahan dan ketetapan informasi dalam pengambilan keputusan. Komputerisasi sebagai suatu penerapan tekhnologi yang dapat membantu kelancaran sistem promosi dan sebagainya, sehingga penyelesain suatu masalah dan pengambilan keputusan dapat di lakukan secara tepat.

Walaupun perkembangan ilmu pengetahuan dan teknologi sudah semakin pesat, masih banyak permasalahan dan kelemahan sistem yang ada pada suatu organisasi atau usaha sehingga perlu adanya sistem yang baru. Pada era globalisasi dewasa ini perlu adanya strategi dan teknik yang dapat di gunakan sebagai pendukung dalam membantu pencapaian tujuan organisasi atau usaha, termasuk juga pada perusahaan Multicom.
Multicom merupakan usaha yang bergerak dalam bidang penjualan laptop beserta aksesoris, yang menjalankan usahanya guna memenuhi kebutuhan sehari-hari masyarakat yang ada di sekitar tempat usahanya dan di luar.

Permasalahan yang terjadi pada outlet Multicom yaitu sistem promosi yang ada masih menggunakan sistem dari mulut ke mulut, sehingga menyebabkan usahanya lambat berkembang.

\section{Metode Penelitian}

\section{A. Metode Pengumpulan Data}

Metode pengumpulan data yaitu mendapatkan data dengan cara :

1) Observasi

Meninjau dan mengunjungi langsung ke Multicom untuk mengetahui secara keseluruhan tentang masalah yang akan dibahas.

2) Wawancara

Wawancara langsung kepada bagian yang berkepentingan untuk mengumpulkan data-data yang dibutuhkan.

\section{3) Studi Kepustakaan}

Dilakukan dengan cara membaca buku-buku yang berkaitan dengan masalah penjualan. Penelitian kepustakaan ini secara teoritis sangat membantu didalam pembuatan tugas akhir ini.

\section{B. Analisa Sistem}

Salah satu pendekatan pengembangan sistem adalah pendekatan Analisa Object Oriented. Kegiatan yang dilakukan pada tahap ini adalah

- Menganalisa sistem yang ada, yaitu memahami proses bisnis sistem yang sedang berjalan guna mengidentifikasikan permasalahan - permasalahan yang ada.

- Analisa dokumen, yaitu menspesifikasikan masukan yang digunakan, database yang ada, proses yang dilakukan dan keluaran yang 
dihasilkan, guna memahami kebutuhan akan dokumen-dokumen yang baru.

\section{TINJAUAN PUSTAKA}

Aplikasi adalah program yang digunakan untuk melakukan sesuatu pada sistem komputer, sekalipun aplikasi disertakan sebagai bagian dari sistem operasi yang menjalankan komputer secara langsung. Selanjutnya ini biasa dikatakan bahwa semua aplikasi adalah program, tetapi tidak semua program dikatakan aplikasi.

Aplikasi adalah sebuah program yang dapat dieksekusi yang datanya disediakan dalam bentuk :

- Aplikasi yang disertakan dalam sumbernya.

- Mengirimkannya oleh program yang sedang dijalankan pengguna sebagai input.

- Informasi yang diberikan sebagai parameter perintah nilai atau sistem operasi

\section{A. Definisi Sistem}

Dewasa ini penggunaan kata sistem semakin meluas dan meliputi berbagai bidang, sehingga timbul berbagai definisi dan istilah tentang sistem tersebut yang masingmasing beranjak dari sudut pandang dan lingkup pengertian itu sendiri. Pada dasarnya kata sistem berasal dari bahasa Yunani "Sytema" yang berarti kesatuan, yakni keseluruhan dari bagian-bagian yang mempunyai hubungan satu sama lain. Teori tentang sistem menurut beberapa pakar adalah sebagai berikut : Sistem adalah suatu jaringan kerja dari prosedur - prosedur yang saling berhubungan, berkumpul bersama - sama untuk melakukan suatu kegiatan atau untuk menyelesaikan suatu sasaran yang tertentu.

\section{B. SMS (Short Message Service)}

\section{1) Definisi $S M S$}

SMS adalah sebuah layanan pegiriman pesan singkat dari dan ke handphone ataupun telepon. Layanan ini disebut layanan pesan singkat karena memang lebar karakternya hanya sebanyak 160 karakter alfanumerik dan tidak berisi gambar atau grafik. Suatu provider telepon seluler pasti menyediakan layanan ini sebagai salah satu layanan utama provider tersebut. SMS didukung oleh GMS, TDMA, CDMA yang berbasis pada telepon seluler yang saat ini banyak digunakan. Karena layanan berbasis SMS telah banyak digunakan selama beberapa tahun terakhir ini, maka penetrasi telepon seluler dan user yang banyak menggunakan layanan ini sudah membuat layanan berbasis SMS menjadi sebuah layanan menarik. Sekarang ini otomatis dalam layanan ini dimanfaatkan untuk berkomunikasi secara singkat pada para konsumen suatu perusahaan. Contohnya adalah layanan pesan antar yang menggunakan SMS, ataupun layanan informasi yang secara otomatis mereply pada para pelanggan. Penambahan fungsi SMS sebagai alat pengirim pesan singkat dari pengguna ke pengguna lainnya sebenarnya bukan merupakan solusi dari hasil pemikiran serius. Namun demikian pada akhirnya SMS menjadi sukses secara tak terduga sebagai layanan messaging paling populer di dunia. Hal ini tentunya memberikan pendapatan ekstra bagi operator jaringan yang akan memperoleh bayaran untuk tiap kiriman SMS melalui jaringannya.

\section{2) Karakteristik SMS}

Ada beberapa karakteristik pesan SMS yang penting yaitu :

- Pesan SMS dijamin sampai atau tidak sama sekali selayaknya e-mail, sehingga jika terjadi kegagalan sistem atau hal lain yang menyebabkan pesan SMS tidak diterima akan diberikan informasi (report) yang menyatakan pesan SMS gagal dikirim

- Berbeda dengan fungsi call (panggilan), sekalipun saat mengirimkan SMS handphone tujuan tidak aktif bukan berarti pengiriman SMS akan gagal. Namun SMS akan masuk ke antrian dulu selama belum time-out. SMS akan segera dikirmkan jika handphone sudah aktif.

- Bandwith yang digunakan rendah.

\section{3) Keuntungan SMS}

Pada tingkat minimun, keuntungan yang dapat diberikan oleh SMS bagi pemakai meliputi: pengiriman nonifikasi dan peringatan (alert), penyampaian pesan yang terjamin, handal, mekanisme komunikasi dengan dengan biaya rendah, kemampuan untuk menyaring pesan dan menanggapi panggilan secara selektif, meningkatnya produktifitas pelanggan. Untuk fungsionalitas yang canggih, SMS memberikan beberapa keuntungan tambahan bagi pelanggan yaitu pengiriman pesan kebeberapa pelanggan sekaligus, kemampuan menerima informasi yang beragam, integrasi dengan aplikasi data dan aplikasi berbasis internet lainnya. Jadi secara umum keuntungan SMS bagi pelanggan adalah kenyamanan, fleksibilitas, dan integrasi yang tak kentara antar layanan pesan dan akses data. Keberhasilan dan popularitas SMS antara lain disebabkan oleh :

- Harga per kiriman tetap/konstan. Apabila beban biaya telepon bervariasi maka beban biaya kiriman SMS tetap/konstan. Hal ini berpengaruh terutama kepada pelanggan yang menggunakan kartu GSM pra-bayar yang mempunyai kredit pulsa terbatas pada telepon selulernya.

- Keamanan dan kesopanan. Apabila kita hendak menggunakan telepon seluler di tempat umum, maka berbicara menggunakannya dirasakan kurang sopan dan kurang aman, namun sebaliknya berkirim pesan menggunakan SMS adalah lebih sopan dan privacy lebih terjaga. 
- Tidak mengganggu penerima. Seperti halnya e-mail, SMS sebagai alat komunikasi tidak mengganggu penerima, karena penerima bisa memutuskan kemudian kapan dan dimana dia akan menjawab pesan tersebut.

- Handal ( reliable ). Jaringan GSM secara umum diakui kehandalannya dalam mengirimkan data, dan SMS mewarisi kehandalan tersebut. Tidak seperti pager, ketika pesan SMS terkirim dan masuk ke gateway dan gateway berhasil mengirimkannya ke nomor tujuan, gateway kemudian mengirim pesan acknowledgement ke pengirim bahwa pesan telah terkirim

\section{4) Cara Kerja SMS}

Dalam sistem SMS, mekanisme utama yang dilakukan dalam sistem adalah melakukan pengiriman short message dari satu terminal ke terminal yang lain. Hal ini dapat dilakukan berkat adanya sebuah entitas dalam sistem SMS yang bernama Short Message Service Center (SMSC), disebut juga Message Center (MC). Pengiriman pesan SMS secara store and forward yaitu pengirim SMS memasukkan pesan SMS dan nomor tujuan dan kemudian mengirimkannya (store) ke server SMS (SMS Center) yang kemudian bertanggung jawab mengirimkan pesan SMS tersebut (forward) ke nomor telapon tujuan. Didalamnya termasuk penentuan atau pencarian rute tujuan akhir dari short message dari berbagai sumber seperti Voice Mail System (VMS), Web-based messaging, E-mail Integration, External Short Messaging Entities (ESME), dan lain-lain.

Hal ini berarti bahwa pengirim dan penerima SMS tidak perlu berada dalam status berhubungan (connected/online) satu sama lain ketika akan saling bertukar pesan SMS. Pengiriman pesan SMS secara store and forward berarti pengirim pesan SMS menuliskan pesan dan nomor telepon tujuan dan kemudian mengirimkannya (store) ke server SMS (SMS-Center) yang kemudian bertanggung jawab untuk mengirimkan pesan tersebut (forward) ke nomor telepon tujuan. Hal ini mirip dengan mekanisme store and forward pada protokol SMTP yang digunakan dalam pengiriman e-mail internet. Keuntungan mekanisme store and forward pada SMS adalah, penerima tidak perlu dalam status online ketika ada pengirim yang bermaksud mengirimkan pesan kepadanya. Karena pesan akan dikirim oleh pengirim ke SMSC yang kemudian dapat menunggu untuk meneruskan pesan tersebut ke penerima ketika ia siap dan dalam status online di lain waktu.

\section{Perangkat Lunak Yang Digunakan}

Bahasa Java tentunya sudah tidak asing lagi bagi kita, selain terkenal dengan motto-nya yaitu "write once run everywhere", penggunaan java juga telah semakin meluas dari aplikasi berbasis web sampai dengan peralatanperalatan yang bersifat mobile, seperti handphone. Pada kesempatan ini kita juga menggunakan bahasa java untuk membuat aplikasi SMS server.

\section{Pengenalan Java}

Java adalah bahasa pemrograman yang berorientasi objek ( Object Oriented Programing ) dan dapat dijalankan pada berbagai platform sistem operasi. Perkembangan java tidak hanya terfokus pada satu sistem operasi, tetapi dikembangkan untuk berbagai sistem operasi dan bersifat open source. Meskipun java dapat berjalan pada platform selain Windows, penulis sengaja menggunakan Windows sebagai sistem operasinya dengan alasan banyak orang yang telah paham dengan lingkungan sistem operasi ini. Pemindahan aplikasi yang akan kita buat nanti ke sistem operasi selain Windows semisal Linux tidak banyak melakukan perubahan. Adapun yang perlu diperhatikan adalah paket koneksi Java ke serial port (serial driver) dan database (database driver). Versi java yang penulis gunakan adalah j2sdk.1.6.

\section{E. MySQL}

MySQL merupakan database server dimana pemrosesan data terjadi di server, dan client hanya mengirimkan data serta meminta data. Oleh karena pemrosesan terjadi di server sehingga pengaksesan data tidak terbatas.

MySQL mempunyai lisensi yang cukup kompleks, yaitu jiak diinstal pada sistem operasi Microsoft Windows adalah shareware tetapi tidak mempunyai expired date. Sedangkan jika diinstal pada sistem operasi selain Microsoft Windows adalah free sesuai dengan dengan General Public Licence (GPL).

MySQL termasuk dalam kategori database management system, yaitu database yang terstruktur dalam pengolahan dan penampilan data. Ada beberapa alasan mengapa MySQL menjadi program database yang sangat populer dan digunakan oleh banyak orang. Alasan-alasan di antaranya adalah :

- MySQL merupakan database yang memiliki kecepatan yang tinggi dalam melakukan perosesan data, dapat diandalkan dan mudah digunakan serta mudah dipelajari.

- MySQL mendukung mendukung banyak bahasa pemrograman seperti C, C++, Perl, Phython, Java, Visual Basic dan PHP.

- MySQL dapat menangani database dengan skala yang sangat besar dengan jumlah record mencapai lebih dari 50 juta.

- MySQL merupakan software database yang bersifat free atay gratis, jadi kita tidak perlu susahsusah mengeluarkan uang hanya untuk sekedar membaya lisensi. 
Berikut beberapa istilah database yang akan sering dipakai dalam MySQL :

- Database adalah kelompok informasi yang diatur berhubungan dengan pengolahan data, penyediaan informasi dan penggunaan referensi.

- Field adalah tempat, diman informasi ditampung

- Record adalah kumpulan informasi yang berhubungan dengan informasi di fields.

\section{HASIL DAN PEMBAHASAN}

\section{A. Analisa Masalah}

Dengan banyaknya perusahaan yang mulai bermunculan dalam memasarkan barang atau produk mereka ke masyarakat secara luas, maka Multicom dituntut untuk membuat suatu terobosan baru didalam memberikan layanan bagi pelanggannya. Terlebih dalam hal mempromosikan barang atau produk yang mereka jual.

Pada Multicom, pemesanan barang atau produk masih dilakukan secara manual, dimana dalam melakukan pemesanan barang atau produk, pelanggan harus melalui telepon maupun datang langsung untuk mendapatkab informasi mengenai barang atau produk, harga maupun ketersediaan barang atau produk yang mereka beli. Selain itu juga pihak perusahaan didalam menyampaikan informasi dan pemesanan barang atau produk yang mereka jual mengharuskan mereka datang langsung ketempat pelanggan untuk mendapatkan informasi yang mereka butuhkan. Jika menggunakan telepon, pelanggan harus menunggu antrian jawaban telepon. Dengan banyaknya pelanggan, tidak jarang informasi dari pelanggan tidak dilayani dengan baik oleh pihak perusahaan. Sedangkan jika pelanggan datang langsung terkadang barang atau produk yang mereka inginkan tidak ada. Dengan kondisi seperti ini membuat pelayanan terhadap pelanggan kurang efisien serta pelanggan akan merasa tidak puas dan beralih ke perusahaan lain yang pelayanannya lebih baik.

Agar Perusahaan ini tidak mengalami kerugian dan kebangkrutan, maka perusahaan harus memberikan kepuasaan terhadap pelanggana agar mereka tetap membeli barang atau produk yang berkualitas dengan pelayanan yang mudah, cepat, efisien.

Untuk mengatasi masalah tersebut, dibutuhkan suatu aplikasi terkomputerisasi yang dapat menghimpun jenis dan harga barang atau produk tersebut sehingga memudahkan mereka memperoleh barang atau produk yang dibutuhkan. Aplikasi yang dibuat haruslah up to date agar dapat memberikan kepuasan kepada pelanggan dan juga masyarakat yang ingin menjadi pelanggan.

\section{B. Analisa Sistem Yang Berjalan}

Permasalahan yang selama ini terjadi adalah bagaimana mencari solusi untuk membantu pelanggan mengetahui barang atau produk yang mereka pesan masih ada atau tidak dan mempermudah pelanggan dalam memesan suatu barang atau produk sehingga pelanggan dengan segera mendapatkan barang atau produk yang diinginkan. Dengan dibuatnya program aplikasi yang mendukung dalam memberikan layanan informasi dan transaksi bagi pelanggan. Aplikasi SMS Server dapat dijadikan suatu jawaban karena aplikasi ini mempermudah pelanggan untuk mendapatkan informasi dan melakukan transaksi pemesanan barang atau produk yang diinginkan, pelanggan tidak perlu lagi menunggu terlalu lama barang yang dipesan, pelanggan cukup mengetik SMS untuk memperoleh informasi dan melakukan transaksi pemesanan yang diinginkan. Keuntungan yang didapatkan jika menggunakan aplikasi ini adalah mempermudah serta membuat lebih efektif dan efisien dalam hal penerimaan maupun pengiriman informasi dan melakukan transaksi pemesanan barang atau produk melalui SMS Pelanggan juga Pelanggan juga akan mendapatkan info yang dapat memudahkan dalam melakukan pemesanan seperti ingin mengetahui format pengetikan SMS dan mereka bisa memberikan komentar berupa saran atau keluhan yang mereka temui ketika melakukan pemesanan barang atau produk.

\section{Analisa Proses/Activity Diagram}

Hasil analisa terhadap proses yang berlangsung sekarang ini dimodelkan dengan activity diagram berikut ini:

\section{1) Activity Diagram Pemesanan Barang ke Distributor}

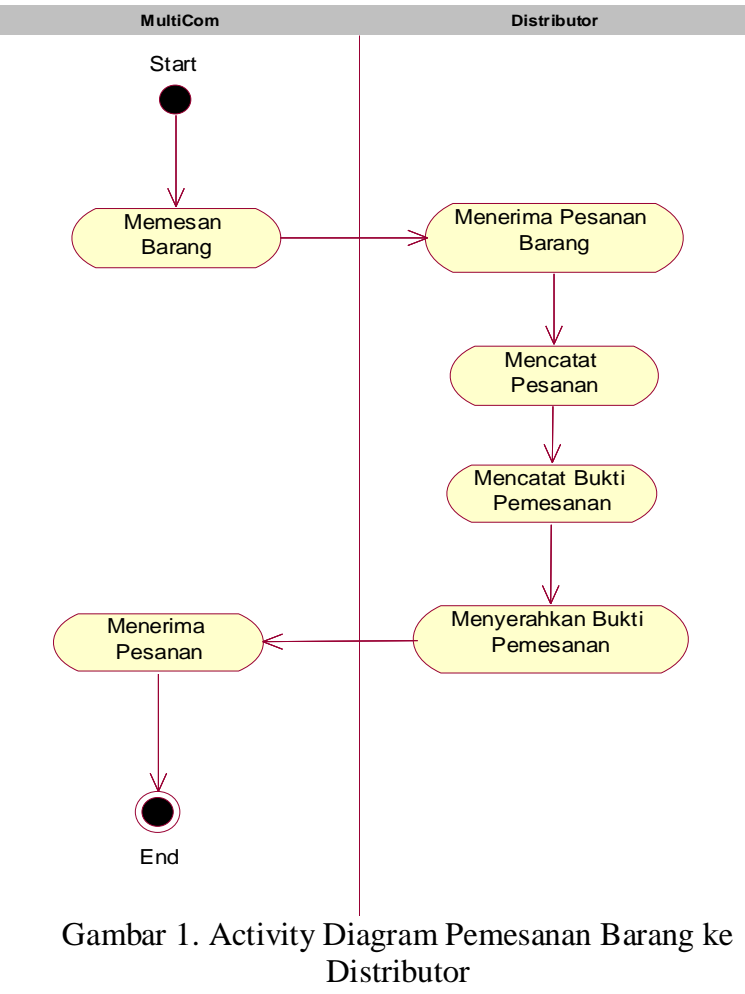


2)

Activity Diagram Pemesanan Barang ke Multicon

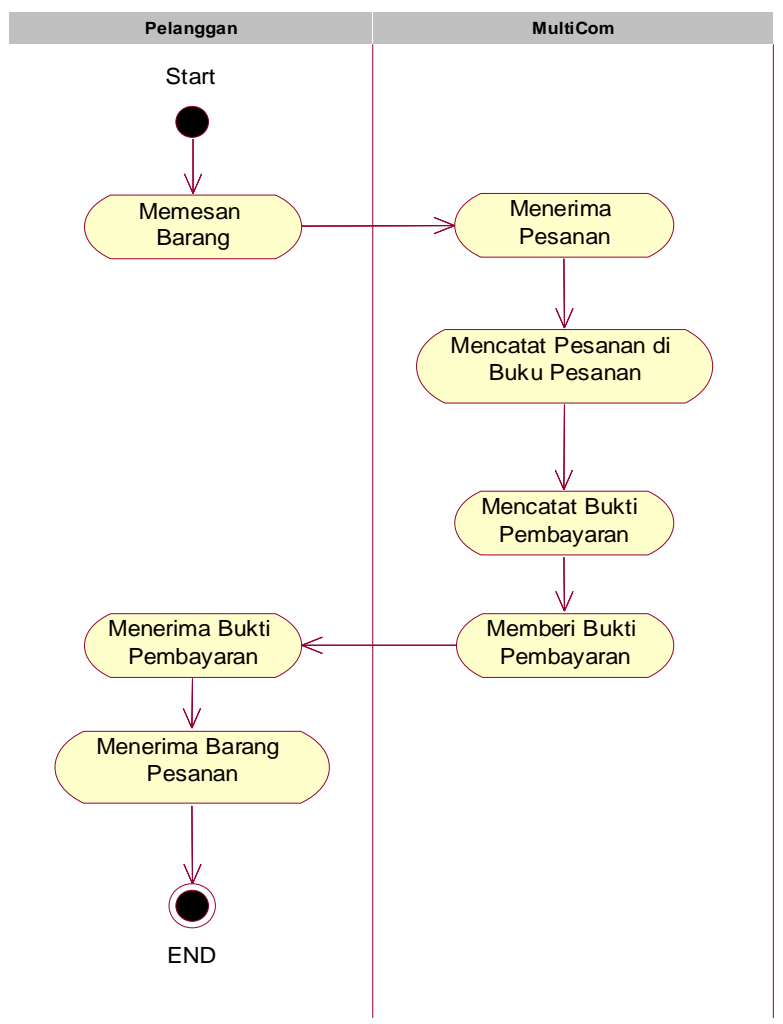

Gambar 2. Activity Diagram Pemesanan Barang ke Multicon

3) Activity Diagram Catat Data Barang

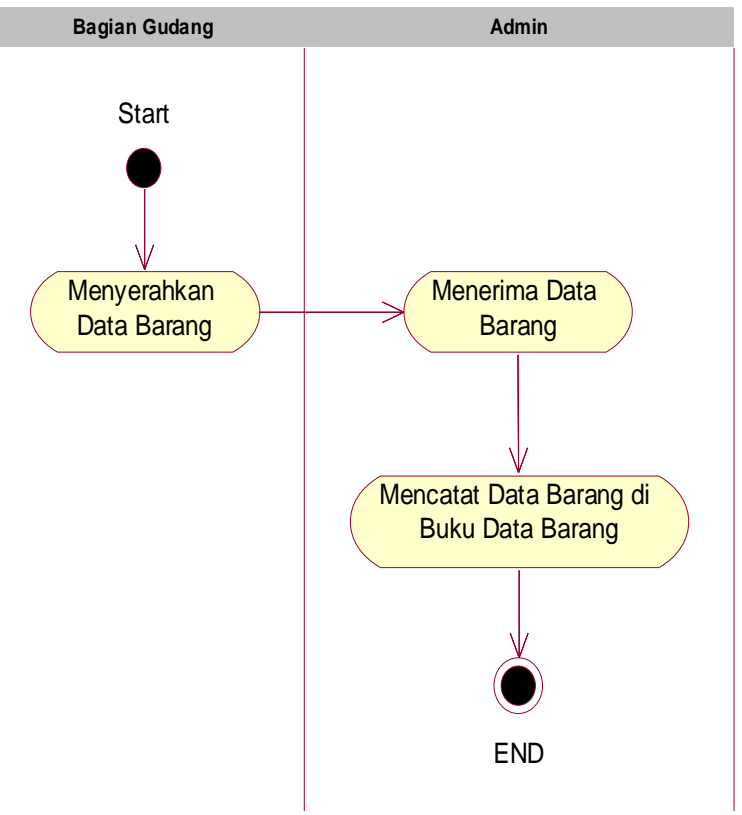

Gambar 3. Activity Diagram Catat Data Barang
4) Activity Diagram Catat Data Pelanggan

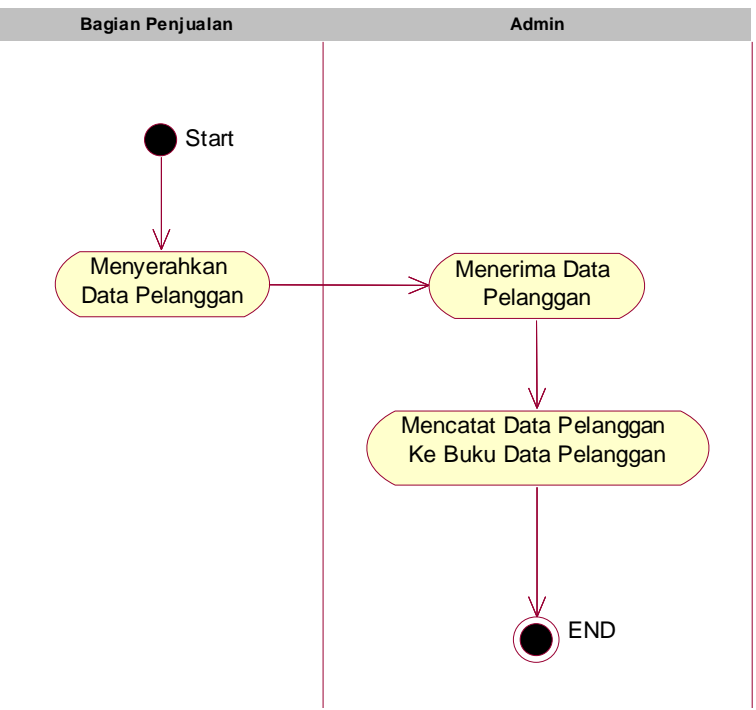

Gambar 4. Activity Diagram Catat Data Pelanggan

D. Use Case Diagram

1) Pelanggan

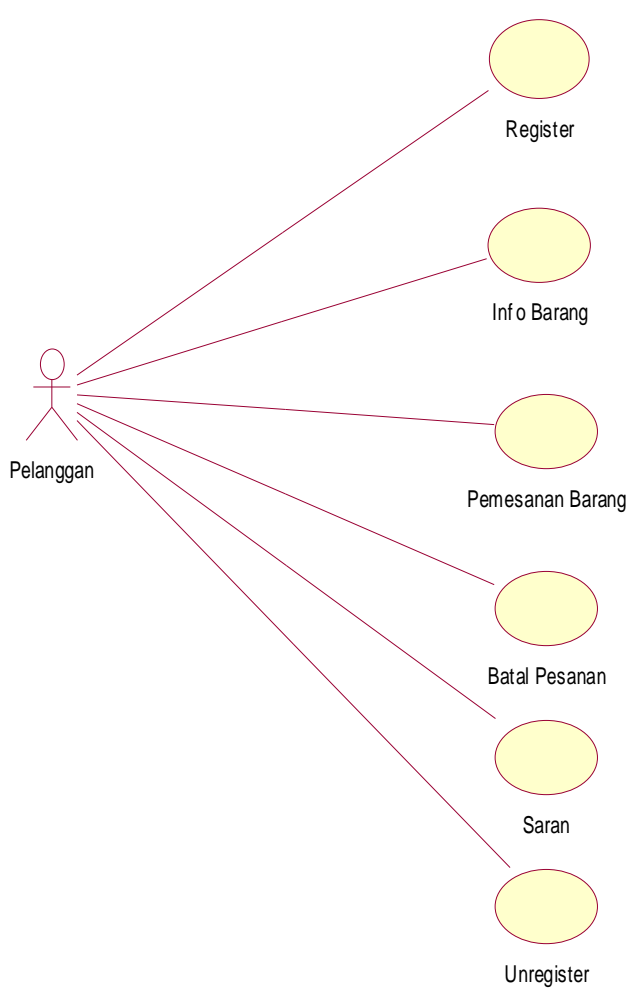

Gambar 5. Use Case Pelanggan 
2) Admin

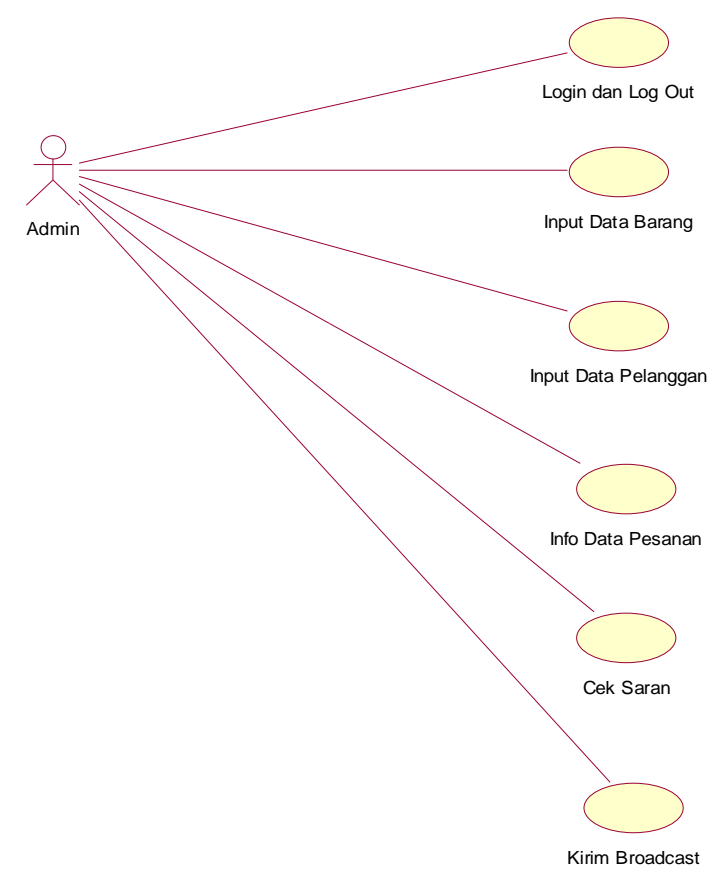

Gambar 6. Use Case Admin

\section{E. Perancangan Sistem}

Dari hasil analisa sistem yang berjalan dapat dibuat rancangan untuk sistem yang akan diajukan, sehingga dapat dibentuk rancangan basis data yang akan mempermudah hubungan antara satu tabel dengan yang lainnya dan memiliki tugas database yang penting dalam sistem . Ada beberapa teknik yang digunakan dalam perencangan basis data seperti ERD (Entity Relations Diagram), Transformasi ERD ke LRS (Logical Record structure), Spesifikasi Basis Data. Database ini terdiri dari data yang digunakan untuk mempermudah terhadap pengguna sesuai tugas dan fungsinya.

\section{F. Rancangan Layar}

Suatu aplikasi akan didapat baik apabila memenuhi beberapa kriteria tentang pemrograman, yang salah satunya adalah memiliki struktur tampilan antarmuka yang baik. Hal ini akan membuat pengguna aplikasi merasa nyaman dan tidak mudah jenuh dalam menggunakannya. Dibawah ini adalah beberapa rancangan layar yang digunakan sebagai berikut :

1) Rancangan Layar Aplikasi Server

Aplikasi ini merupakan sebuah aplikasi yang di install pada komputer dan digunakan sebagai aplikasi yang menangani semua proses request dari client secara otomatis. Dalam aplikasi ini Admin juga dapat melakukan beberapa proses yang lain misalnya memasukkan data master, pengiriman SMS (Broadcast) dan lainnya. Berikut ini adalah rancangan layar dari beberapa tampilan yang memiliki fungsinya masing-masing.

\section{2) Rancangan Layar Menu Utama}

Pada Menu Utama ini terdapat 4 menu yaitu Menu File Multicom, Master Multicom, SMS Server \& Broadcast, dan About. Masing-masing menu memilik submenu jika diklik. Untuk menjalankan aplikasi dan mendapatkan informasi yang diinginkan, maka admin dapat membuka form-form lainnya melalui menu yang sudah disediakan. Seperti membuka Master Multicom untuk memanipulasi data, membuka Form SMS Server untuk melakukan pengiriman SMS kepada pelanggan serta menampilkan form-form lainnya sesuai dengan fungsi dan kegunaanya. Untuk lebih jelas dapat dilihat pada gamba rancangan layar di bawah ini :

\section{Aplikasi Pemesanan Online Mealui Website Berbasis Sws Gateway Pada Multicom}

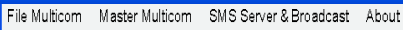

Login

Logoff
Keller

Selarmat Da.ang: Malara Sao.tza

Gambar 7. Rancangan Layar Menu Utama

\section{3) Rancangan Layar Login}

Di awal pemakaian aplikasi ini akan menampilka Form Login. Pada aplikasi ini seorang Admin yang ingin menggunakan aplikasi ini harus melakukan pengisian Username dan Password secara benar pada Textfield yang telah disediakan untuk digunakan sebagai validasi pengguna system. Apabila Login berhasi maka akan muncul Form Menu Utama, namun apabila login gagal akan ada keluar "Password yang anda masukkan salah" atau "User Id tidak terdaftar" maka Form Menu Utama tidak dapat digunakan. Untuk lebih jelasnya dapat dilihat pada gambar dibawah ini :

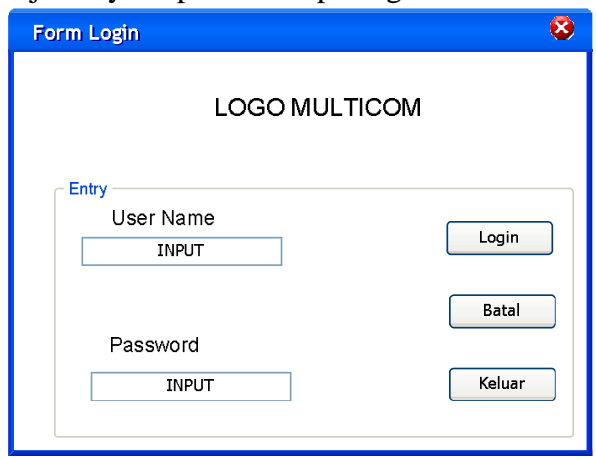

Gambar 8. Rancangan Layar Login 


\section{G. Implmenetasi Aplikasi SMS Gateway}

Pada aplikasi server ini, aplikasi akan berjalan dan siap digunakan untuk mengirim maupun menerima SMS jika admin yang berhasil melakukan proses login telah melakukan koneksi antara komputer dengan handphone sebagai modem GSM melalui kabel data dan memilih port virtual yang dihasilkan ketika handphone sudah berhasil terhubung ke komputer dengan baik dan benar. Berikut dibawah ini akan dijelaskan bagaimana proses koneksi antara komputer dengan handphone.

\section{1) Tampilan Layar Form Login}

Pada tampilan layar Form Login ini terdapat Username dan Password serta tombol Login untuk masuk ke system, tombol Batal untuk mengosongkan Username dan Password, dan juga tombol Keluar untuk menutup Form Login dan masuk ke Menu Utama.

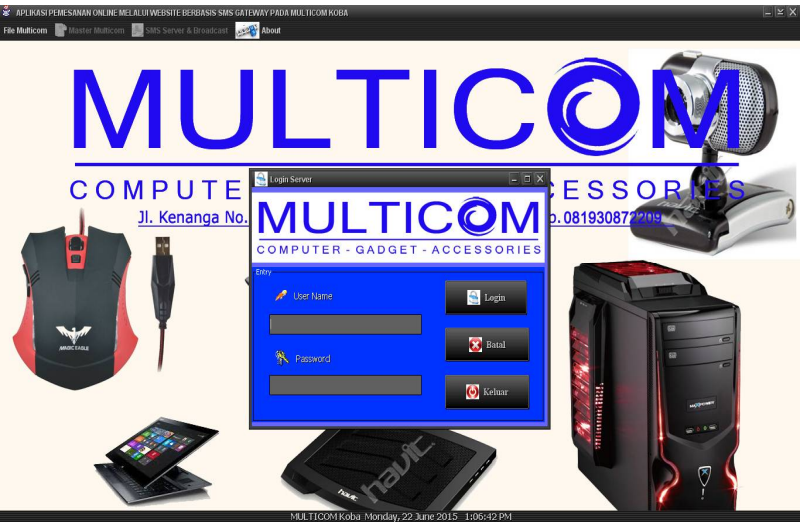

Gambar 9. Tampilan Layar Login

\section{2) Tampilan Layar Menu Utama}

Dalam Menu Utama terdapat 4 menu yang dimana setiap menu masih memiliki beberapa bagian dalam masing-masing menu, ke 4 menu awal yaitu meliputi Menu File Multicom, Master Multicom, SMS Server \& Broadcast, dan Abut. Berikut tampilan dapat dilihat pada gambar dibawah ini :

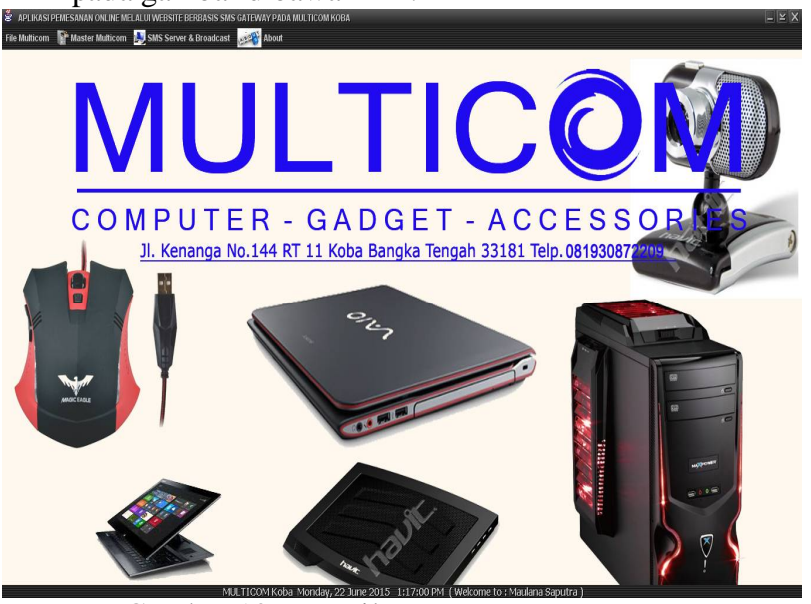

Gambar 10. Tampilan Layar Menu Utama

\section{3) Request Reg}

Request ini berfungsi untuk melakukan pendaftaran pelanggan terhadapa aplikasi SMS Server ini, agar pelanggan terdaftar pada database aplikasi SMS Server ini. Format pesan yang akan dikirim oleh pelanggan adalah ketik REG<space>Nama\#NoKTP\#Alamat

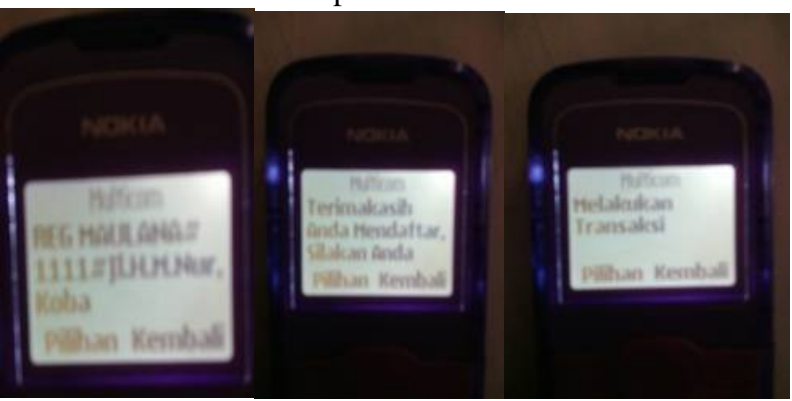

Gambar 11. Tampilan Layar di Request Reg

4) Request Help

Request Help berfungsi untuk mengetahui semua kode request yang bisa dilakukan oleh planggan dengan format. HELP

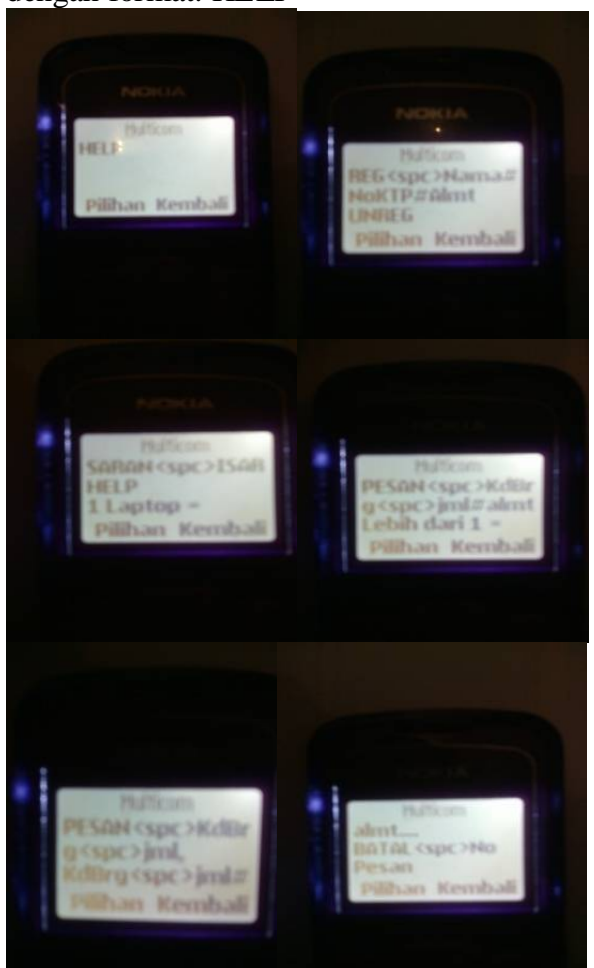

Gambar 12. Tampilan Layar di Request Help 


\section{A. Kesimpulan}

Dari hasil analisa terhadap masalah dan aplikasi yang dikembangkan, maka dapat diambil beberapa kesimpulan, antara lain :

- Tersedianya aplikasi pemesanan barang pada Multicom yang berbasis SMS gateway.

- Dengan adanya Aplikasi SMS Gateway, Pelanggan dapat melakukan request dan mengetahui informasi tentang barang, stok, dan harga barang yang diinginkan dimanapun dan kapanpun.

- Dengan aplikasi SMS Gateway ini, segala macam bentuk informasi serta transaksi pemesanan barang yang bersangkutan dapat dilakukan kapanpun dan dimanapun pelanggan berada.

- Pihak Multicom Koba, Bangka Tengah akan lebih mudah dalam mengumumkan atau menyampaikan informasi kepada semua pelanggan.

B. Saran

Saran-saran yang memungkinkan bisa dijadikan pertimbangan untuk pengembanganaplikasi ini lebih lanjut, antara lain:

- Perlu ditambah fitur-fitur yang lebih lengkap, sehingga mampu memenuhi kebutuhan yang lebih baik

- Informasi yang diakses melalui SMS hanya sebatas kepada pelanggan, maka perlu ditambahkan informasi-informasi lain yang sesuai dengan kebutuhan pada Multicom

- Pada spesifikasi program yang dibutuhkan setidaknya harus sesuai dengan perkembangan teknologi tidak terpaku pada system operasi windows xp saja.

- Perawatan dan pemeliharan aplikasi dan komponen pendukung aplikasi harus diperhatikan, jika tidak apalikasi tidak akan berjalan dengan baik.

\section{DAFTAR PUSTAKa}

[1] Sutabri, Tata. Analisis Sistem Informasi. Yogyakarta: Penerbit Andi, 2012.

[2] Sutabri, Tata. Konsep Sistem Informasi. Yogyakarta: Penebit Andi, 2012.

[3] Whitten, Jeffery L, Lonnie D.Bentley, Kevin C. Dittman, System Analysis and Design Method, 6th ed. New York : McGraw-Hill, 2004.

[4] Widjaya, Iwan Kurniawan. Manajemen Proyek Teknologi Informasi. Jakarta: Graha Il mu, 2013. 